\title{
Motivating Children and Adolescents in Obesity Treatment
}

\author{
Sarah Woo', Kyung Hee Park ${ }^{2, *}$ \\ ${ }^{1}$ Major in Biomedical Science, Department of Medical Sciences, Hallym University College of Medicine, Chuncheon; ${ }^{2}$ Department of Family Medicine, Hallym \\ University Sacred Heart Hospital, Hallym University College of Medicine, Anyang, Korea
}

Enhancing motivation is a crucial issue in pediatric obesity interventions, as behavioral changes related to food intake and physical exercise are difficult to carry out with an insufficient level of motivation. In the treatment setting, low motivation towards change may lead to early termination or inadequate treatment outcomes. This paper reviews widely-used models of motivation, including the transtheoretical model of change, self-determination theory, and motivational interviewing (MI). We introduce useful strategies based on each theoretical model to enhance motivation, such as an importance and confidence scale and a decisional balance technique. A review of recent $\mathrm{Ml}$ interventions in children and adolescents is presented to discuss the efficacy of MI-based interventions and considerations for applying Ml in pediatric obesity.

Key words: Pediatric obesity, Motivation, Motivational interviewing, Behavior therapy, Health behavior, Theoretical model

\author{
Received March 25, 2020 \\ Reviewed April 10, 2020 \\ Accepted April 26, 2020 \\ ${ }^{*}$ Corresponding author \\ Kyung Hee Park \\ (i) \\ https://orcid.org/0000-0001-9806-0076 \\ Department of Family Medicine, \\ Hallym University Sacred Heart Hospital, \\ Hallym University College of Medicine, \\ 22 Gwanpyeong-ro 170beon-gil, \\ Dongan-gu, Anyang 14068, Korea \\ Tel: $+82-31-380-3805$ \\ Fax: +82-31-380-1782 \\ E-mail: beloved920@gmail.com
}

\section{INTRODUCTION}

Treating pediatric obesity is challenging as treatment choices are often limited due to developmental issues. For children and adolescents, lifestyle changing intervention is mainstay in the treatment of obesity. ${ }^{1,2}$ There are critical issues to consider when applying lifestyle changing interventions to the pediatric population: limited effectiveness, high dropout rate, and low level of motivation to change are important considerations in pediatric obesity. ${ }^{3-5}$ To ensure treatment effectiveness, it is crucial to assess a patient's motivation to change and provide adequate strategies to enhance motivation for enacting lifestyle changes.

The purpose of this review is to examine theoretical and treatment approaches to enhance motivation in pediatric obesity. We discuss common approaches directed at changing motivation, including the transtheoretical model of change (TTM), self-determination theory (SDT), and motivational interviewing (MI). ${ }^{6,7} \mathrm{We}$ also discuss various treatment modalities to induce obesity-related behavioral changes, such as social cognitive theory, ${ }^{8}$ motivational enhancement therapy, ${ }^{9}$ and health action process approach. ${ }^{10} \mathrm{Re}-$ cent intervention studies based on MI and their effectiveness in treating pediatric obesity are also summarized.

\section{TRANSTHEORETICAL MODEL}

Many lifestyle changing interventions focus on 'changing behavior' as a component of the treatment. However, many patients are not ready to initiate behavior change when they enter treatment,

Copyright (C) 2020 Korean Society for the Study of Obesity

(a) This is an Open Access article distributed under the terms of the Creative Commons Attribution Non-Commercial License (https://creativecommons.org/licenses/by-nc/4.o/) which permits unrestricted non-commercial use, distribution, and reproduction in any medium, provided the original work is properly cited 
and may not benefit sufficiently from these action-oriented programs. ${ }^{11}$ TTM provides a useful theoretical tool to distinguish different stages of readiness for behavioral change related to obesity. This helps to determine which treatment strategies would be most useful to enhance motivation according to the patient's stage. ${ }^{12,13}$

According to the TTM, change is a process that progresses across time through five stages: precontemplation, contemplation, preparation, action, and maintenance. ${ }^{11}$ During precontemplation, patients may be unmotivated. Patients in this stage may refuse to discuss losing weight. Contemplation is a stage in which people acknowledge that there is a problem and consider changing behaviors, such as changing their diet or increasing physical activity, but ambivalence towards change limits them from making a commitment. Preparation is a stage in which people intend to make a change in the near future and have started implementing small changes, such as taking the stairs. These people may benefit from action-oriented obesity interventions. Action is a stage with overt behavioral changes; in this stage, patients may initiate considerable efforts into making these changes. Lastly, maintenance is a stage in which people gain confidence in maintaining behavioral change. The treatment goal for this stage is to prevent relapse. ${ }^{11,14,15}$

The stages of change model demonstrates that different treatment modalities are recommended for different stages of change. ${ }^{16}$ The proportion of children in each stage of change regarding physical activity and dietary behaviors varies widely across samples.
Children in the precontemplation and contemplation stages ranged from as little as $17.3 \%$ to as much as $78.7 \%$, while participants in the preparation and action stages ranged from $25.2 \%$ to $64.6 \%$ in previous obesity intervention studies. ${ }^{12,17,18}$ Clinicians should be aware that patients visiting the clinic range broadly regarding readiness to change. Patients in the early stages require strategies such as consciousness raising and discussing cost and benefits to enhance motivation to initiate change, while people in the preparation and action stages may benefit more from action-oriented strategies, such as stimulus control and reinforcement management. ${ }^{15,16}$ Identification of stages and intervention strategies for each stage of change are presented in Table 1.11,13,14

Guidelines may be helpful in clinical practice. First, a patient's stage of change should be assessed to set adequate treatment goals for his or her readiness for change. Simple questions will assess a patient's actual practice of the target behavior and intention to engage in such behavior in the future (Table 1). The stages of change can be assessed separately on specific target behaviors, such as "taking the stairs," "eating fruits for snacks," and "drinking low-fat milk," so that it is easier for both the patient and the clinician to set specific treatment goals. ${ }^{13}$

Second, the treatment goal should be realistic and include a plan to advance one stage at a time. It may not be helpful to expect a patient in the precontemplation stage to achieve direct action goals at the first treatment attempt, such as cutting back on soda completely.

Table 1. Stages and components of transtheoretical model $11,13,14$

\begin{tabular}{|c|c|c|c|}
\hline Stages of change & Description & Assessment question* & Intervention strategy \\
\hline Precontemplation & $\begin{array}{l}\text { Is unaware of need to change and does not } \\
\text { have intention to change }\end{array}$ & $\begin{array}{l}\text { "Do you do the (target behavior) less than half the time now, and have } \\
\text { no plans to do it within the next } 6 \text { months?" }\end{array}$ & $\begin{array}{l}\text { - Consciousness raising } \\
\text { - Dramatic relief } \\
\text { - Environmental reevaluation } \\
\text { - Providing information about change }\end{array}$ \\
\hline Contemplation & $\begin{array}{l}\text { Has intention to change but experiences } \\
\text { ambivalence towards change }\end{array}$ & $\begin{array}{l}\text { "Do you do the (target behavior) less than half the time now, but are } \\
\text { thinking about doing it sometime within the next } 6 \text { months?" }\end{array}$ & $\begin{array}{l}\text { - Self-reevaluation } \\
\text { - Cost and benefits }\end{array}$ \\
\hline Preparation & $\begin{array}{l}\text { Is preparing to take action and make plans } \\
\text { related to change }\end{array}$ & $\begin{array}{l}\text { "Do you do the (target behavior) less than half the time now, but are } \\
\text { making definite plans to start doing it within this month?" }\end{array}$ & $\begin{array}{l}\text { - Self-liberation } \\
\text { - Goal-setting }\end{array}$ \\
\hline Action & $\begin{array}{l}\text { Engages in change or modifying behavior } \\
\text { (less than } 6 \text { months) }\end{array}$ & $\begin{array}{l}\text { "Do you do the (target behavior) at least half the time now, and have } \\
\text { just started doing it within the last } 6 \text { months?" }\end{array}$ & $\begin{array}{l}\text { - Counterconditioning } \\
\text { - Helping relationships } \\
\text { - Reinforcement } \\
\text { - Stimulus control } \\
\text { - Encouragement }\end{array}$ \\
\hline Maintenance & $\begin{array}{l}\text { Sustains changed behavior for more than } \\
6 \text { months }\end{array}$ & $\begin{array}{l}\text { "Do you do the (target behavior) at least half the time now, and have } \\
\text { been doing it for more than } 6 \text { months now?" }\end{array}$ & -Relapse prevention \\
\hline
\end{tabular}

${ }^{*}$ Questions are implemented from Weight Loss Behavior-Stage of Change Scale. ${ }^{13}$ 
Rather than risking early termination by imposing action on nonmotivated patients, ${ }^{19}$ it may be helpful to work on enhancing motivation prior to taking action. ${ }^{15}$

Third, treatment strategies should be adequately matched to a patient's stage of change. For example, it may not be effective to implement behavioral changing strategies in patients at the precontemplation and contemplation stages, as these changes may be temporary without intrinsic motivation. Instead, strategies to enhance motivation are required, such as giving obesity-related health risk feedback to activate emotional responses (dramatic relief), increasing awareness about the causes and consequences for obesity (consciousness raising), and helping to realize how personal behaviors affect social relationships and the environment (environmental reevaluation). Meanwhile, it is equally insufficient to apply motivational strategies when a patient is ready to change. Behavioral techniques such as stimulus control and reinforcement can help more to accomplish behavior changes at this stage. ${ }^{11,15,16}$

\section{SELF-DETERMINATION THEORY}

While TTM focuses on the "level" or "quantity" of motivation, determining the "type" and "quality" of motivation may also be important to engage patients in lifestyle changing behaviors. ${ }^{20}$ SDT, suggested by Deci and Ryan, ${ }^{21,22}$ introduces a theoretical framework to understand the quality of different types of motivations and how they affect behavior. According to the SDT, motivation can be distinguished as amotivation, extrinsic motivation, and intrinsic motivation. Whereas extrinsic motivation is a type of motivation in which the behavior is a means of achieving external outcomes, intrinsic motivation arises when the behavior is satisfactory in itself. ${ }^{23,24}$ There are four different types of extrinsic motivation, which vary on a spectrum according to the degree of internalization and autonomy. Types of motivational regulation and examples related to physical activity are described in Table $2 .^{23-26}$

To determine whether a change will persist, a patient's level of autonomy and degree of internalization regarding his or her motivation should be evaluated. More self-regulatory motivation regarding exercise behavior is related to the amount of physical activity and maintenance of weight loss. ${ }^{24,25}$ Even when patients seem to be equally motivated (e.g., preparation stage), sometimes it is not enough to understand the motives behind the action. For example, a child stops drinking soda after a doctor's visit where the child learns that he or she has to lose weight to get healthy (identified regulation). This behavior may have a higher chance of lasting than a child who stops drinking soda to refrain from his or her parent's scolding (external regulation). A behavior has an even higher chance of lasting when it is done for intrinsic reasons. A child playing basketball because it is fun may keep playing even after he or she has lost a considerable amount of weight (intrinsic regulation). ${ }^{20}$

Most of the work with SDT and obesity is focused on the moti-

Table 2. Motivational regulations according to self-determination theory ${ }^{23-26}$

\begin{tabular}{|c|c|c|c|}
\hline $\begin{array}{l}\text { Type of motivational } \\
\text { regulations }\end{array}$ & Type of motivation & Description & Motivational source \\
\hline Amotivation & Amotivation & Has no reason or intention to engage in the target behavior & $\begin{array}{l}\text { None (e.g., does not engage in physical activity even though } \\
\text { one is advised to do so) }\end{array}$ \\
\hline External regulation & Extrinsic motivation & $\begin{array}{l}\text { Motivated by external controls prescribed by others. May only } \\
\text { temporarily control behavior and is likely to show minimal } \\
\text { effort }\end{array}$ & $\begin{array}{l}\text { - Gaining rewards } \\
\text { - Avoiding punishment (e.g., exercises to receive allowance } \\
\text { promised by parents) }\end{array}$ \\
\hline Introjected regulation & & $\begin{array}{l}\text { Motivated by internal pressure from internalized constructs of } \\
\text { external controls. Does not truly value the behavior and may } \\
\text { experience inner conflict }\end{array}$ & $\begin{array}{l}\text { - Feeling self-approval } \\
\text { - Avoiding feeling guilty (e.g., exercises after heavy meal } \\
\text { because one is affected by societal ideal of thinness) }\end{array}$ \\
\hline Identified regulation & & $\begin{array}{l}\text { Motivated because behavior is perceived as important and } \\
\text { useful. The behavior is usually a means to achieve certain } \\
\text { outcomes }\end{array}$ & $\begin{array}{l}\text { - Outcomes of behavior (e.g., exercises to get healthy or lose } \\
\text { weight) }\end{array}$ \\
\hline Integrated regulation & & $\begin{array}{l}\text { Motivated because the behavior is in concordance with one's } \\
\text { values and sense of self. Stable and persistent type of } \\
\text { motivation }\end{array}$ & $\begin{array}{l}\text { - Feeling of identification (e.g., plays soccer as a sports player, } \\
\text { which is an important part of one's identity) }\end{array}$ \\
\hline Intrinsic regulation & Intrinsic motivation & $\begin{array}{l}\text { Motivated because behavior is interesting and exciting in } \\
\text { itself. A person engages in the behavior willingly and with } \\
\text { self-determination }\end{array}$ & $\begin{array}{l}\text { - Enjoyment } \\
\text { - Pleasure } \\
\text { - Fun (e.g., riding a bicycle because it is enjoyable) }\end{array}$ \\
\hline
\end{tabular}


vation for engaging in physical activity. ${ }^{20,27}$ Although research targeting the pediatric population is scarce, studies in the adult population showed that autonomous or intrinsic motivation predicts higher rates of attendance, exercise, weight loss, and weight loss maintenance after intervention. ${ }^{24,28-31}$ SDT-based obesity interventions that included setting value-relative goals and enhancing enjoyment were successful in reinforcing motivation and also increased the amount of physical exercise. . $7,29,32$ Some effective strategies included exploring the value of exercise other than weight management and presenting various exercise options to discover a physical activity that is personally enjoyable. ${ }^{31}$

Other strategies based on SDT may also be useful to promote autonomous motivation. First, refrain from the use of external incentives, such as giving rewards for exercise, as this will undermine the sense of autonomy and internal locus of causality. Also, provide a list of options to choose from, as physical activity or dietary plans corresponding to the patient's preference are more likely to be congruent with his or her internal goals and values. Lastly, rather than using coercive statements such as "you should exercise" or "you must lose weight," use neutral terms and give objective reasons for adopting a health-related behavior to help a patient to examine the rationale and make a choice on his or her own behalf. ${ }^{24}$

\section{MOTIVATIONAL INTERVIEWING}

\section{Strategies of MI}

Finally, MI is a powerful tool widely used to promote behavior change. Motivational changes that occur through MI can be explained through the theoretical framework of TTM and SDT. The key principles and strategies of $\mathrm{MI}$ are similar to concepts from TTM and SDT, especially the importance of resolving ambivalence and enhancing autonomous motivation to change. $23,24,33,34$

$\mathrm{MI}$ is a particularly useful tool with a distinctive style of interacting with patients and providing strategies to work on behavioral change. ${ }^{23}$ The main elements of MI are distinguished into relational and technical components. ${ }^{33}$ The relational component is the "spirit of MI," or the clinician's interpersonal qualities in being empathetic and collaborative with a patient. ${ }^{35}$ The technical component is a variety of strategies used to motivate patients to pursue change, such as expressing empathy, reflective listening, rolling with resistance, eliciting statements of motivation, and developing discrepan$\mathrm{cy}^{2,3,24,36}$ In contrast to conventional approaches that use a confronting and directive style of interaction, $\mathrm{MI}$ avoids imposing action or directly persuading a patient to change and instead interacts with patients to support their autonomy. ${ }^{37}$

Although MI was first developed as a counseling method, with adequate training, many practitioners can use it for pediatric obesity treatment, including nurses, dieticians, and physicians. ${ }^{24}$ The American Academy of Pediatrics has recommended MI as an approach for treating pediatric obesity. ${ }^{36,38} \mathrm{MI}$ used in combination with other forms of treatment, such as behavioral therapy, is known to be effective. ${ }^{24}$ The common components and strategies of MI that can be used to treat pediatric obesity are described in Table $3{ }^{36,39-41}$

\section{Recent MI interventions}

Evidence has shown that $\mathrm{MI}$ is effective in leading health-related behavioral change during obesity treatment in the adult population. ${ }^{38,42,43}$ Meanwhile, the relatively few studies that have examined the efficacy of MI in children and adolescents with obesity have shown mixed rsesults. ${ }^{44-47} \mathrm{~A}$ recent meta-analysis on the effectiveness of MI to treat adolescents with obesity yielded a nonsignificant overall reduction in body mass index (BMI) z-score and other cardiometabolic outcomes, such as insulin and triglycerides. ${ }^{47}$ However, some promising outcomes were reported related to increased health-related behaviors and quality of life. ${ }^{46,47}$

A meta-analysis on children with obesity treated with MI also presented mixed results regarding treatment outcomes. ${ }^{45}$ Three trials included in the review demonstrated that $\mathrm{MI}$ intervention is more effective than usual care in decreasing BMI, while three other trials showed null effects regarding BMI. ${ }^{45}$ In parallel with interventions in adolescents, $\mathrm{MI}$ interventions targeting children also showed improvements in behavioral outcomes, such as decreased calorie intake, ${ }^{48}$ less consumption of snacks and soda, ${ }^{49}$ and decreased screen time. ${ }^{50}$

Although there is still insufficient data to draw conclusions about the efficacy of MI as a strategy to treat pediatric obesity, ${ }^{51}$ we looked at some of the most recent MI interventions since the latest metaanalysis on adolescents ${ }^{47}$ and children. ${ }^{45} \mathrm{~A}$ brief review of recent studies on the effectiveness of MI in pediatric obesity are presented in Table 4. ${ }^{5,52-55}$ 
Table 3. Ml strategies and examples for children with obesity ${ }^{36,39-41}$

\begin{tabular}{|c|c|c|}
\hline Main Ml technique & Description and rationale & Example \\
\hline Agenda setting & $\begin{array}{l}\text { Collaboratively sets session agenda } \\
\text { - Offers the patient control over course of action } \\
\text { - Patient is more likely to participate actively in conversation. }\end{array}$ & $\begin{array}{l}\text { "Would it be okay to talk about your weight today?" } \\
\text { "Which of the topics, exercise or reducing screen time, would } \\
\text { you like to talk about today?" }\end{array}$ \\
\hline Reflective listening & $\begin{array}{l}\text { Rephrasing what patients have said and clarifying implicit or explicit } \\
\text { emotions and meanings of what patients intended } \\
\text { - Expresses empathy } \\
\text { - Facilitates patient's self-disclosure and expression of feelings }\end{array}$ & $\begin{array}{l}\text { "Here is how I heard what you were saying. On one hand, you } \\
\text { don't want to give up on drinking soda. On the other hand, } \\
\text { you feel the need to change to become healthy." }\end{array}$ \\
\hline Open-ended questions & $\begin{array}{l}\text { Questions that can be answered using patient's own words and not } \\
\text { answered with restricted forms of "yes" or a "no" } \\
\text { - Provides more information and details about the patient } \\
\text { - Gives patients the opportunity to explore and express their thoughts } \\
\text { and feelings }\end{array}$ & $\begin{array}{l}\text { "Tell me about your concerns related to increasing physical } \\
\text { activity." (Instead of "Are you concerned about increasing } \\
\text { physical activity?") }\end{array}$ \\
\hline Importance and confidence scales & $\begin{array}{l}\text { Scale questions ask degree of importance and confidence in achieving } \\
\text { certain behavior on a scale of } 1 \text { to } 10 \text { to assess motivation and } \\
\text { self-efficacy } \\
\text { - Change talk can be elicited when patients explain why they did not } \\
\text { choose a lower number } \\
\text { - Helps to identify obstacles related to change and factors that can help } \\
\text { in achieving success }\end{array}$ & $\begin{array}{l}\text { "On a scale from } 0 \text { to } 10, \text { how important is it for you to lose } \\
\text { weight?" } \\
\text { "On the same scale, how confident are you that you can lose } \\
\text { weight?" } \\
\text { "Why didn't you give a lower number?" } \\
\text { "What is needed to get to a higher number?" }\end{array}$ \\
\hline Decisional balance technique & $\begin{array}{l}\text { Discuss patient's ambivalence towards change by examining pros and } \\
\text { cons of changing behavior } \\
\text { - Helps clarify reasons for ambivalent attitude towards change }\end{array}$ & $\begin{array}{l}\text { "What are the things you like about eating snacks at night?" } \\
\text { "What are some of the bad things about eating snacks at } \\
\text { night?" } \\
\text { "What reasons are particularly important to you?" }\end{array}$ \\
\hline $\begin{array}{l}\text { Develop discrepancy between actual } \\
\text { and desired behavior }\end{array}$ & $\begin{array}{l}\text { Promote awareness of how patient's current behaviors are inconsistent } \\
\text { with his or her important values and goals } \\
\text { - Resolves ambivalence towards change }\end{array}$ & $\begin{array}{l}\text { "How do you want to be living in } 5 \text { years from now, when you } \\
\text { are a grown-up?" } \\
\text { "Is there any behavior that you are doing now that may get in } \\
\text { the way of these goals?" }\end{array}$ \\
\hline Affirming autonomy & $\begin{array}{l}\text { Avoids confronting or imposing behavior on patient and emphasizes } \\
\text { freedom of personal choice and responsibility } \\
\text { - Acknowledges that patients are experts in their own lives } \\
\text { - Enhances intrinsic motivation. }\end{array}$ & $\begin{array}{l}\text { "It is up to you to decide whether or not you want to start } \\
\text { exercise, and to choose which way works best for you." }\end{array}$ \\
\hline Supporting self-efficacy & $\begin{array}{l}\text { Noticing and encouraging patient's strengths and efforts } \\
\text { - Facilitates the ability of patients to make their own change } \\
\text { - Exploring patient's past successes and acknowledging strengths } \\
\text { enhances self-efficacy }\end{array}$ & $\begin{array}{l}\text { "Can you tell me about a past experience when you tried to } \\
\text { lose weight and succeeded?" } \\
\text { "How you tried participating in the PE class is very } \\
\text { impressive." }\end{array}$ \\
\hline Eliciting change talk & $\begin{array}{l}\text { Reinforcing change talk, which is patient's own motivational statements } \\
\text { of expressing desire to change } \\
\text { - Change talk best predicts actual behavior change }\end{array}$ & $\begin{array}{l}\text { "What do you expect to happen if you don't make any changes } \\
\text { regarding your diet?" } \\
\text { "How do you think this behavior would affect your future if it } \\
\text { kept going?" }\end{array}$ \\
\hline $\begin{array}{l}\text { Providing information or advice with } \\
\text { permission }\end{array}$ & $\begin{array}{l}\text { Asking permission to discuss subject before offering information, } \\
\text { suggestions, or advice } \\
\text { - Asking permission before providing information lowers patient's } \\
\text { resistance } \\
\text { - Helps to enhance willingness to hear information }\end{array}$ & $\begin{array}{l}\text { "Can I share some information with you about the benefits of } \\
\text { exercising?" } \\
\text { "Would it be okay if I share some useful tips that worked for } \\
\text { other kids who have the same worries as you?" }\end{array}$ \\
\hline Summarizing & $\begin{array}{l}\text { Restating what patient had said with a summary } \\
\text { - Demonstrates that clinician has been listening } \\
\text { - Patients are more likely to be motivated by hearing what they have } \\
\text { said, instead of what other people have told them. }\end{array}$ & $\begin{array}{l}\text { "Could I go over what we have discussed so far today? From } \\
\text { what I understand..." }\end{array}$ \\
\hline
\end{tabular}

$\mathrm{Ml}$, motivational interviewing; PE, physical education.

Two trials each on adolescents and children were identified. Three of the four studies were relatively brief, ranging from 3 to 10 sessions, ${ }^{52-54}$ while the Fit Families trial was a more intensive intervention with an average of 21 sessions applied over 7 months. ${ }^{5}$ The results imply that brief forms of $\mathrm{MI}$ counseling may be useful in treating pediatric obesity. ${ }^{52-54}$ Brief interventions were effective, and more intensive intervention was not more beneficial.

While recent updates of the MI-based obesity intervention in 
Table 4. Review of recent Ml intervention trials in pediatric obesity

\begin{tabular}{|c|c|c|c|c|c|}
\hline Author (year) & Study design & Subject & Duration (follow-up) & Intervention (session) & Outcome \\
\hline $\begin{array}{l}\text { Freira et al. } \\
(2018,2019)^{54,55}\end{array}$ & Cluster RCT & $\begin{array}{l}\text { - } 97 \text { Participants ( } 14-19 \text { years) } \\
\text { - Overweight }\end{array}$ & $\begin{array}{l}\text { - } 3 \text { Months (6 months } \\
\text { follow-up) } \\
\text { - } 83(85.6 \%) \text { Completed }\end{array}$ & $\begin{array}{l}\text { - Cl: } 3 \text { sessions } \\
\text { - Ml: } 3 \text { sessions }\end{array}$ & $\begin{array}{l}\text { - Ml group: BMl z-score } \downarrow, W C \downarrow \text {, fat } \\
\text { mass } \downarrow \text {, muscle mass } \uparrow, S B P \downarrow, D B P \downarrow \\
\text { - Cl group: WC } \uparrow \text {, fat mass } \uparrow \text {, muscle } \\
\text { mass } \downarrow, H R O \circ \downarrow \downarrow\end{array}$ \\
\hline $\begin{array}{l}\text { Naar et al. }(2019)^{5} \\
\text { (fit families) }\end{array}$ & $\begin{array}{l}\text { Sequential multiple } \\
\text { assignment } \\
\text { randomized trial }\end{array}$ & $\begin{array}{l}\text { - } 181 \text { Participants (12-17 years) } \\
\text { - BMI } \geq 95 \text { th percentile for age } \\
\text { and sex }\end{array}$ & $\begin{array}{l}\text { - } 7 \text { Months } \\
-156(86 \%) \text { Completed }\end{array}$ & $\begin{array}{l}\text { - Home-based Ml: } 12 \\
\text { sessions+RP/CS/CM (3 mo) } \\
\text { - Office-based Ml: } 12 \\
\text { sessions+RP/CS/CM (3 mo) }\end{array}$ & $\begin{array}{l}\text { All groups: weight loss } 3.20 \% \text { (no } \\
\text { group difference) }\end{array}$ \\
\hline $\begin{array}{l}\text { Resnicow et al. } \\
(2016)^{53}\left(\mathrm{BMI}^{2}\right)\end{array}$ & Cluster RCT & $\begin{array}{l}\text { - } 645 \text { Participants ( } 2-8 \text { years) } \\
\text { - } \text { BMI } \geq 85 \text { th, } \leq 97 \text { th for age and } \\
\text { sex }\end{array}$ & $\begin{array}{l}\text { - } 2 \text { Years } \\
\text { - } 457(71 \%) \text { Completed }\end{array}$ & $\begin{array}{l}\text { - Usual care } \\
\text { - PCP: } 3 \text { Ml sessions, } 1 \text { booster } \\
\text { session (PCP) } \\
\text { - PCP+RD: } 3 \text { Ml sessions, } \\
1 \text { booster session (PCP), } \\
6 \text { sessions (RD) }\end{array}$ & $\begin{array}{l}\text { - BMl percentile, fruit and vegetable } \\
\text { intake: } \mathrm{PCP}+\mathrm{RD}<\text { usual care } \\
\text { - Screen time: } \mathrm{PCP}+\mathrm{RD}<\mathrm{PCP} \text {, usual } \\
\text { care }\end{array}$ \\
\hline $\begin{array}{l}\text { Broccoli et al. } \\
(2016)^{52}\end{array}$ & RCT & $\begin{array}{l}\text { - } 372 \text { Participants ( } 4-7 \text { years) } \\
\text { - BMl } \geq 85 \text { th, } \leq 95 \text { th for age and } \\
\text { sex }\end{array}$ & $\begin{array}{l}\text { - } 12 \text { Months ( } 24 \text { months } \\
\text { follow-up) } \\
\text { - } 337(91 \%) \text { Completed }\end{array}$ & $\begin{array}{l}\text { - Usual care } \\
\text { - Ml: } 5 \text { sessions }\end{array}$ & 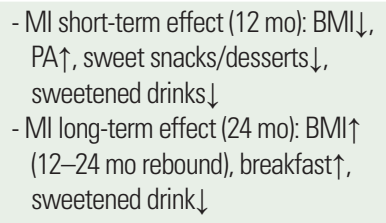 \\
\hline
\end{tabular}

Ml, motivational interviewing; RCT, randomized controlled trial; Cl, conventional intervention; BMI, body mass index; WC, waist circumference; SBP, systolic blood pressure; DBP, diastolic blood pressure; HROoL, health-related quality of life; RP, relapse prevention; CS, continued skills; CM, contingency management; PCP, primary care providers; RD, registered dietitians; PA, physical activity.

children and adolescents demonstrated successful weight loss after MI treatment, the effect was modest. ${ }^{5,53,54}$ Broccoli et al. ${ }^{52}$ indicated that although MI was more effective than usual care after 12 months of intervention, the MI group showed a rebound effect of weight increase during the $12-24$ month period of maintenance. One trial reported that cardiometabolic parameters, such as waist circumference, blood pressure, and fat mass, decreased with a larger effect size than BMI z-score change. ${ }^{54}$

As suggested by previous literature, MI may have a more direct effect on behavioral changes related to food intake and enhanced physical activity. At least short-term effects of MI on food intake were reported, including increased fruit and vegetable intake, vegetable soup intake, and decreased sweet snacks, candy, desserts, and sweetened drinks intake. ${ }^{52,53}$ Behavioral changes associated with physical activity including decreased screen time and enhanced non-organized physical activity were also significant. ${ }^{52,53}$ Health-related quality of life was improved with MI. ${ }^{55}$ This result is reasonable, as the primary focus of $\mathrm{MI}$ is not to decrease weight but to enhance motivation to engage in specific behavioral changes. ${ }^{47}$ The effective communication facilitated through $\mathrm{MI}$ is also associated with other treatment-related factors, such as patient satisfaction and adherence to treatment recommendations..$^{33,56}$
Other considerations when applying $\mathrm{MI}$ in pediatric obesity include the phase of treatment in which MI is most effective. MI may work best in the initial stages of intervention, whereas motivational issues should be used to engage patients in treatment and behavioral change. ${ }^{1,57}$ Even an MI session delivered over the phone prior to treatment initiation was shown to be effective in increasing treatment adherence. ${ }^{56}$ Once the issues with motivation are thoroughly addressed, more direct modes of intervention should be added, such as behavioral therapy or cognitive behavioral therapy. ${ }^{57,58}$

It is also possible to consider different options when deciding on the treatment mode of MI. Interventions that explored the outcomes of MI delivered by telephone demonstrated its effectiveness, ${ }^{59,60}$ and the effect of home-based MI was not different from that of office-based intervention. ${ }^{5}$ While MI-based text-messaging may not have a direct effect on decreased BMI, it may be a useful supplementary tool because it increases adherence to treatment and behavioral changes. ${ }^{61,62}$

\section{CONCLUSION}

To address the crucial issue of enhancing motivation in pediatric obesity, we assessed several models of motivation, including TTM, 
SDT, and MI. These treatment modules were initially applied in the field of addiction treatment, but have been extended for use in a variety of behavioral interventions including obesity. ${ }^{47}$ TTM is particularly useful in assessing a patient's readiness to engage in behavioral change and setting goals. SDT enhances understanding of a patient's motivational causes by examining types of motivation, which are distinguished by the level of autonomy. Lastly, MI is a practical approach frequently used in obesity treatment that encompasses the theoretical framework of TTM and SDT to present a variety of strategies for use in clinical practice. Because each patient's motivational status for behavioral change is different, it is crucial to comprehend the level and content of a patient's motivation and deliver an intervention tailored to each patient. TTM, SDT, and MI can serve as useful theoretical approaches to guide this process and enhance motivation to treat pediatric obesity.

\section{CONFLICTS OF INTEREST}

The authors declare no conflict of interest.

\section{AUTHOR CONTRIBUTIONS}

Study concept and design: KHP and SW; drafting of the manuscript: KHP and SW; critical revision of the manuscript: KHP and SW; and study supervision: KHP.

\section{REFERENCES}

1. Brown CL, Perrin EM. Obesity prevention and treatment in primary care. Acad Pediatr 2018;18:736-45.

2. Park KH. Intervention for severely obese children and adolescents. J Obes Metab Syndr 2019;28:1-3.

3. Hoelscher DM, Butte NF, Barlow S, Vandewater EA, Sharma SV, Huang T, et al. Incorporating primary and secondary prevention approaches to address childhood obesity prevention and treatment in a low-income, ethnically diverse population: study design and demographic data from the Texas Childhood Obesity Research Demonstration (TX CORD) study. Child Obes 2015;11:71-91.

4. Oude Luttikhuis H, Baur L, Jansen H, Shrewsbury VA, O'alley
C, Stolk RP, et al. Interventions for treating obesity in children. Cochrane Database Syst Rev 2009;(1):CD001872.

5. Naar S, Ellis D, Idalski Carcone A, Jacques-Tiura AJ, Cunningham $\mathrm{P}$, Templin $\mathrm{T}$, et al. Outcomes from a sequential multiple assignment randomized trial of weight loss strategies for African American adolescents with obesity. Ann Behav Med 2019;53:928-38.

6. Ceccarini M, Borrello M, Pietrabissa G, Manzoni GM, Castelnuovo G. Assessing motivation and readiness to change for weight management and control: an in-depth evaluation of three sets of instruments. Front Psychol 2015;6:511.

7. Pietrabissa G, Manzoni GM, Corti S, Vegliante N, Molinari E, Castelnuovo G. Addressing motivation in globesity treatment: a new challenge for clinical psychology. Front Psychol 2012;3:317.

8. Bagherniya M, Taghipour A, Sharma M, Sahebkar A, Contento IR, Keshavarz SA, et al. Obesity intervention programs among adolescents using social cognitive theory: a systematic literature review. Health Educ Res 2018;33:26-39.

9. Feld R, Woodside DB, Kaplan AS, Olmsted MP, Carter JC. Pretreatment motivational enhancement therapy for eating disorders: a pilot study. Int J Eat Disord 2001;29:393-400.

10. Parschau L, Barz M, Richert J, Knoll N, Lippke S, Schwarzer R. Physical activity among adults with obesity: testing the health action process approach. Rehabil Psychol 2014;59:42-9.

11. Prochaska JO, Redding CA, Evers KE. The transtheoretical model and stages of change. In: Glanz K, Rimer BK, Viswanath $\mathrm{K}$, editors. Health behavior and health education: theory, research and practice. 4th ed. San Francisco: Jossey-Bass; 2002. p. 97-122.

12. Sanaeinasab H, Saffari M, Nazeri M, Karimi Zarchi A, Cardinal BJ. Descriptive analysis of Iranian adolescents' stages of change for physical activity behavior. Nurs Health Sci 2013; 15:280-5.

13. Sutton K, Logue E, Jarjoura D, Baughman K, Smucker W, Capers C. Assessing dietary and exercise stage of change to optimize weight loss interventions. Obes Res 2003;11:641-52.

14. Beckman H, Hawley S, Bishop T. Application of theorybased health behavior change techniques to the prevention of obesity in children. J Pediatr Nurs 2006;21:266-75. 
15. Norcross JC, Krebs PM, Prochaska JO. Stages of change. J Clin Psychol 2011;67:143-54.

16. Spencer L, Wharton C, Moyle S, Adams T. The transtheoretical model as applied to dietary behaviour and outcomes. Nutr Res Rev 2007;20:46-73.

17. Ham OK, Sung KM, Lee BG, Choi HW, Im EO. Transtheoretical model based exercise counseling combined with music skipping rope exercise on childhood obesity. Asian Nurs Res (Korean Soc Nurs Sci) 2016;10:116-22.

18. Frenn M, Malin S, Villarruel AM, Slaikeu K, McCarthy S, Freeman J, et al. Determinants of physical activity and low-fat diet among low income African American and Hispanic middle school students. Public Health Nurs 2005;22:89-97.

19. Gunnarsdottir T, Njardvik U, Olafsdottir AS, Craighead LW, Bjarnason R. The role of parental motivation in family-based treatment for childhood obesity. Obesity (Silver Spring) 2011; 19:1654-62.

20. Teixeira PJ, Silva MN, Mata J, Palmeira AL, Markland D. Motivation, self-determination, and long-term weight control. Int J Behav Nutr Phys Act 2012;9:22.

21. Deci EL, Ryan RM. A motivational approach to self: integration in personality. Nebr Symp Motiv 1990;38:237-88.

22. Deci E, Ryan RM. Intrinsic motivation and self-determination in human behavior. New York (NY): Plenum; 1985.

23. Markland D, Ryan RM, Tobin VJ, Rollnick S. Motivational interviewing and self-determination theory. J Soc Clin Psychol 2005;24:811-31.

24. Silva MN, Markland D, Minderico CS, Vieira PN, Castro MM, Coutinho SR, et al. A randomized controlled trial to evaluate self-determination theory for exercise adherence and weight control: rationale and intervention description. BMC Public Health 2008;8:234.

25. Gourlan M, Trouilloud D, Sarrazin P. Motivational characteristics of obese adolescents toward physical activity: contribution of self-determination theory. Eur Rev Appl Psychol 2013; 63:209-18

26. Duncan LR, Hall CR, Wilson PM, Rodgers WM. The use of a mental imagery intervention to enhance integrated regulation for exercise among women commencing an exercise program. Motiv Emot 2012;36:452-64.
27. Fortier MS, Duda JL, Guerin E, Teixeira PJ. Promoting physical activity: development and testing of self-determination theory-based interventions. Int J Behav Nutr Phys Act 2012; 9:20.

28. Silva MN, Markland D, Carraça EV, Vieira PN, Coutinho SR, Minderico CS, et al. Exercise autonomous motivation predicts 3-yr weight loss in women. Med Sci Sports Exerc 2011; 43:728-37.

29. Silva MN, Vieira PN, Coutinho SR, Minderico CS, Matos MG, Sardinha LB, et al. Using self-determination theory to promote physical activity and weight control: a randomized controlled trial in women. J Behav Med 2010;33:110-22.

30. Teixeira PJ, Going SB, Houtkooper LB, Cussler EC, Metcalfe LL, Blew RM, et al. Exercise motivation, eating, and body image variables as predictors of weight control. Med Sci Sports Exerc 2006;38:179-88.

31. Hsu YT, Buckworth J, Focht BC, O’Connell AA. Feasibility of a self-determination theory-based exercise intervention promoting healthy at every size with sedentary overweight women: project change. Psychol Sport Exerc 2013;14:283-92.

32. Fortier MS, Sweet SN, O’Sullivan TL, Williams GC. A selfdetermination process model of physical activity adoption in the context of a randomized controlled trial. Psychol Sport Exerc 2007;8:741-57.

33. Carcone AI, Jacques-Tiura AJ, Brogan Hartlieb KE, Albrecht T, Martin T. Effective patient-provider communication in pediatric obesity. Pediatr Clin North Am 2016;63:525-38.

34. Miller WR, Rollnick S. Motivational interviewing: preparing people for change. 2nd ed. New York (NY): Guilford Press; 2002.

35. Miller WR, Rose GS. Toward a theory of motivational interviewing. Am Psychol 2009;64:527-37.

36. Jacques-Tiura AJ, Carcone AI, Naar S, Brogan Hartlieb K, Albrecht TL, Barton E. Building motivation in African American caregivers of adolescents with obesity: application of sequential analysis. J Pediatr Psychol 2017;42:131-41.

37. Saelens BE, Lozano P, Scholz K. A randomized clinical trial comparing delivery of behavioral pediatric obesity treatment using standard and enhanced motivational approaches. J Pediatr Psychol 2013;38:954-64. 
38. Barnes RD, Ivezaj V. A systematic review of motivational interviewing for weight loss among adults in primary care. Obes Rev 2015;16:304-18.

39. Erlandson M, Ivey LC, Seikel K. Update on office-based strategies for the management of obesity. Am Fam Physician 2016;94:361-8.

40. Hollis JL, Williams LT, Collins CE, Morgan PJ. Does motivational interviewing align with international scope of practice, professional competency standards, and best practice guidelines in dietetics practice? J Acad Nutr Diet 2014;114:676-87.

41. Schwartz RP. Motivational interviewing (patient-centered counseling) to address childhood obesity. Pediatr Ann 2010; $39: 154-8$

42. Barlow SE; Expert Committee. Expert committee recommendations regarding the prevention, assessment, and treatment of child and adolescent overweight and obesity: summary report. Pediatrics 2007;120 Suppl 4:S164-92.

43. Frost H, Campbell P, Maxwell M, O’Carroll RE, Dombrowski SU, Williams B, et al. Effectiveness of motivational interviewing on adult behaviour change in health and social care settings: a systematic review of reviews. PLoS One 2018;13: e0204890.

44. Borrelli B, Tooley EM, Scott-Sheldon LA. Motivational interviewing for parent-child health interventions: a systematic review and meta-analysis. Pediatr Dent 2015;37:254-65.

45. Borrello M, Pietrabissa G, Ceccarini M, Manzoni GM, Castelnuovo G. Motivational interviewing in childhood obesity treatment. Front Psychol 2015;6:1732.

46. Cushing CC, Jensen CD, Miller MB, Leffingwell TR. Metaanalysis of motivational interviewing for adolescent health behavior: efficacy beyond substance use. J Consult Clin Psychol 2014;82:1212-8.

47. Vallabhan MK, Jimenez EY, Nash JL, Gonzales-Pacheco D, Coakley KE, Noe SR, et al. Motivational interviewing to treat adolescents with obesity: a meta-analysis. Pediatrics 2018;142: e20180733.

48. Wong EM, Cheng MM. Effects of motivational interviewing to promote weight loss in obese children. J Clin Nurs 2013;22: 2519-30.

49. Davoli AM, Broccoli S, Bonvicini L, Fabbri A, Ferrari E, D’Angelo $S$, et al. Pediatrician-led motivational interviewing to treat overweight children: an RCT. Pediatrics 2013;132:e1236-46.

50. Taveras EM, Gortmaker SL, Hohman KH, Horan CM, Kleinman KP, Mitchell K, et al. Randomized controlled trial to improve primary care to prevent and manage childhood obesity: the High Five for Kids study. Arch Pediatr Adolesc Med 2011; 165:714-22.

51. Tucker SJ, Ytterberg KL, Lenoch LM, Schmit TL, Mucha DI, Wooten JA, et al. Reducing pediatric overweight: nurse-delivered motivational interviewing in primary care. J Pediatr Nurs 2013;28:536-47.

52. Broccoli S, Davoli AM, Bonvicini L, Fabbri A, Ferrari E, Montagna $\mathrm{G}$, et al. Motivational interviewing to treat overweight children: 24-month follow-up of a randomized controlled trial. Pediatrics 2016;137:e20151979.

53. Resnicow K, Harris D, Wasserman R, Schwartz RP, PerezRosas V, Mihalcea R, et al. Advances in motivational interviewing for pediatric obesity: results of the brief motivational interviewing to reduce body mass index trial and future directions. Pediatr Clin North Am 2016;63:539-62.

54. Freira S, Lemos MS, Fonseca H, Williams G, Ribeiro M, Pena F, et al. Anthropometric outcomes of a motivational interviewing school-based randomized trial involving adolescents with overweight. Eur J Pediatr 2018;177:1121-30.

55. Freira S, Fonseca H, Williams G, Ribeiro M, Pena F, do Céu Machado M, et al. Quality-of-life outcomes of a weight management program for adolescents based on motivational interviewing. Patient Educ Couns 2019;102:718-25.

56. Bean MK, Thornton LM, Jeffers AJ, Gow RW, Mazzeo SE. Impact of motivational interviewing on engagement in a parent-exclusive paediatric obesity intervention: randomized controlled trial of NOURISH+MI. Pediatr Obes 2019;14: e12484.

57. Resnicow K, Davis R, Rollnick S. Motivational interviewing for pediatric obesity: conceptual issues and evidence review. J Am Diet Assoc 2006;106:2024-33.

58. Wilfley DE, Hayes JF, Balantekin KN, van Buren DJ, Epstein LH. Behavioral interventions for obesity in children and adults: evidence base, novel approaches, and translation into practice. Am Psychol 2018;73:981-93.

59. Bean MK, Ingersoll KS, Powell P, Stern M, Evans RK, Wick- 
ham EP 3rd, et al. Impact of motivational interviewing on outcomes of an adolescent obesity treatment: results from the MI values randomized controlled pilot trial. Clin Obes 2018; 8:323-6.

60. Bianchi-Hayes J, Schoenfeld E, Cataldo R, Hou W, Messina C, Pati S. Combining activity trackers with motivational interviewing and mutual support to increase physical activity in parentadolescent dyads: longitudinal observational feasibility study. JMIR Pediatr Parent 2018;1:e3.
61. Armstrong S, Mendelsohn A, Bennett G, Taveras EM, Kimberg A, Kemper AR. Texting motivational interviewing: a randomized controlled trial of motivational interviewing text messages designed to augment childhood obesity treatment. Child Obes 2018;14:4-10.

62. Woolford SJ, Clark SJ, Strecher VJ, Resnicow K. Tailored mobile phone text messages as an adjunct to obesity treatment for adolescents. J Telemed Telecare 2010;16:458-61. 